\title{
OPINION
}

\section{THE ORIGINS, EVOLUTION AND OUTSOURCING OF HIV DENIALISM}

Chris Kenyon, $M B$ ChB, BA Hons, $M P H$

Medical Registrar, Groote Schuur Hospital, Cape Town

The HIV denialism propagated in statements such as Mbeki's often repeated 'a virus cannot cause a syndrome' led to the situation where in 2001 only 0.5\% of South Africans believed they had a member of their family infected with HIV. ${ }^{1}$ In such conditions of ignorance and denial few were taking adequate precautions, and the virus was able to spread like wildfire.

Both the origins and subsequent evolution of HIV denialism are rooted in ideology. HIV emerged at a time of great global and local polarisation. The Cold War was raging and the ANC, siding predominantly with the Eastern Block, was engaged in a bitter revolutionary struggle to overthrow the apartheid regime. To counter the brutal 'total onslaught' of the regime, the ANC developed a revolutionary fanaticism of its own. Much of this battle was ideological: to fight against the regime's racist and anti-communist propaganda machine, the ANC aggressively promoted a counter-paradigm in which all issues were seen predominantly in terms of their bearing on the anti-apartheid (and to a lesser extent, anti-capitalist) struggle.

It should come as no surprise, then, that HIV/AIDS was interpreted in this light. There were only two articles in Sechaba (the magazine which was the voice of the ANC in exile) in the 1980s that deal with a specific disease. Both are about AIDS and both are written by Cde. 'Mzala'. In the first article, entitled 'AIDS - misinformation and racism', we are treated in advance to carbon copies of many of Mbeki's favourite gaffes on the subject. ${ }^{2}$ The 'vast majority' of HIV tests done by the ELISA method in Africa are 'false positives' due to Africans' 'sticky blood'. In the second article, entitled 'AIDS and the imperialist connection', we hear that 'the AIDS virus was a product of United States military conspiracy (sic).' The source of this assertion is an '80-page paper' produced by three East German scientists. ${ }^{3}$ Mzala ends with a line that Mbeki will go on to echo: 'AIDS has fallen victim to the same process that has bedeviled health under capitalism, where medical facts are often over-dramatized for the sake of making huge profits for the drugs industry.

As Mbeki's brazen a-virus-can't-cause-a-syndrome brand of denialism attracted increasing ridicule, and with elections approaching in 2003, he was left with two options - back down or adapt. The closest Mbeki came to an admission of error was in his official press release announcing his intention to withdraw from the debate on the link between HIV and AIDS; here he conceded that 'a virus may be one of the causes of AIDS. More recently we were informed that Minister Tshabalala-Msimang will no longer be the government's spokesperson on HIV. The events of the last few years reveal more of an evolution than a renunciation of HIV denialism.

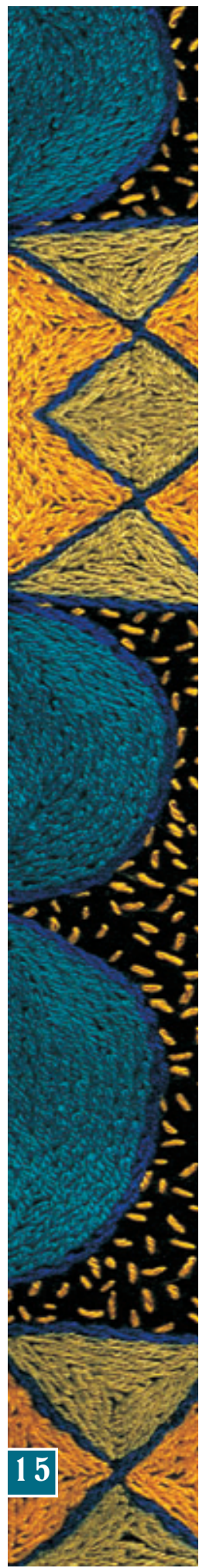


The new form of denialism does not overtly deny the existence of the HIV virus, but rather asserts that AIDS can be treated by proper diet and various nutritional supplements. Furthermore, it claims that antiretrovirals (ARVs) are not only ineffective but actually toxic. Mbeki was one of the first to elaborate this new direction of denialism in his 'Castro Hlongwane' article. ${ }^{4}$ In this document, written on his computer, ${ }^{5}$ he described an unholy alliance or 'omnipotent apparatus' of doctors and pharmaceutical companies who were trying to make a fortune out of poisoning poor Africans with toxic ARVs.

More recently this work has been continued by the Rath Foundation, who have inundated poor communities with leaflets advising them of the lethal toxicity of ARVs, how AIDS can be reversed with Rath's multivitamins, and how these multivitamins herald 'the end of the AIDS epidemic.' The most disturbing aspect of their activities is the active support they have received from officials in the ANC, SANCO and government. SANCO has publicly endorsed many of Rath's claims, ANC branches have been disseminating Rath's material and the National Director General of Health has intervened personally to overturn Medicines Control Council decisions prohibiting the import of unscheduled Rath products into the country. ${ }^{6}$ The National Minister of Health has defended Rath and shared platforms with him on multiple occasions. ${ }^{7}$

Why then is the government supporting the work of an organisation that is seeking to undermine the government's own ARV programme? Once again, part of the answer is ideological - this time in the new neoliberal ideology which has gripped our government. ${ }^{8}$ The first hint of this influence was Mbeki's letter to the cabinet on 6 August 2001 where he implores cabinet members to ensure that spending on AIDS is kept within $2.2 \%$ of total spending so that 'the allocation of resources reflect(s) the incidence of death (from HIV/AIDS).' The extent to which this cost-saving neoliberal ideology has motivated HIV policy was perhaps most chillingly demonstrated by ex-Presidential Spokesperson Parks Mahlanyana who, while himself in the late stages of a wasting disease, announced that the state would not implement a programme to reduce HIV transmission from mothers to their children as this would leave the state with too high a bill of child care maintenance. ${ }^{10}$

The new form of denialism dovetails perfectly with this neoliberal ethos. The neoliberalism justifies the pitiful spending on this social catastrophe, while the new denialism spread by Msimang, Rath and company reduces the demand for and hence the cost of the ARV programme. Mbeki and Msimang may have withdrawn from the public face of the national HIV response, but like good neoliberals they have merely outsourced their denialism to bodies such as the Rath Foundation. That Mbeki continues to be a denialist is clear from the fact that he still refuses to have an HIV test as 'that would reinforce a particular paradigm. Until such time as Mbeki and Msimang offer a meaningful apology to all South
Africans for how they have misled us, and lead us in going for public confidential HIV testing, their views will continue to warp the thinking and practice of millions of South Africans. We should demand nothing less than an unconditional apology from our leaders.

Primo Levi, looking back at the social response to the Nazi genocide, noted: 'And there is another, vaster shame, the shame of the world ... Every bell tolls for everybody. And yet there are those who faced by the crime of others or their own, turn their backs so as not to see it and feel touched by it."1 When Cde. Mzala (Jabulani Nxumalo) and Parks Mahlanyana tragically died in their thirties and forties from 'long illnesses', the bells were ordered to toll for them alone. In a democracy as hard fought for as our own, the fact that we allow our rulers to continue to get away with such actions casts a vast shame on us all.

\section{REFERENCES}

National Youth Survey. National Adolescent Friendly Clinic Initiative. Love Life 2001

2. Nxumalo J. AIDS - misinformation and racism. Sechaba Aug. 1988.

3. Nxumalo J. AIDS and the imperialist connection. Sechaba Sept.1988.

4. Anon. Castro Hlongwane: Cats, Geese and Foot and Mouth Disease http://www.virusmyth.net/aids/data/ancdoc.htm (accessed 10 Sept. 2006).

5. Barrel H. Would the real Aids dissident please stand up. Mail and Guardian 2002; 22 April.

6. Joubert P. Health Department DG frees seized Rath Drugs. Mail and Guardian 2006; 7 July.

7. Joubert P. Deadly silence. Fair Lady 2005; Nov.

8. Bond P. Elite Transition: From Apartheid to Neoliberalism in South Africa. London: Pluto Press, 1996

9. Mbeki questions spending on AIDS. Business Day 2001; 10 Sept. http:// www.bday.co.za/bday/content/direct/1.3523.924850-6078-0.00.html (accessed 10 Sept. 2006).

10. Cohen J. South Africa's new enemy. Science 2000; 288: 2168-2170.

11. Levi P. Survival in Auschwitz. New York: Touchstone, 1995.

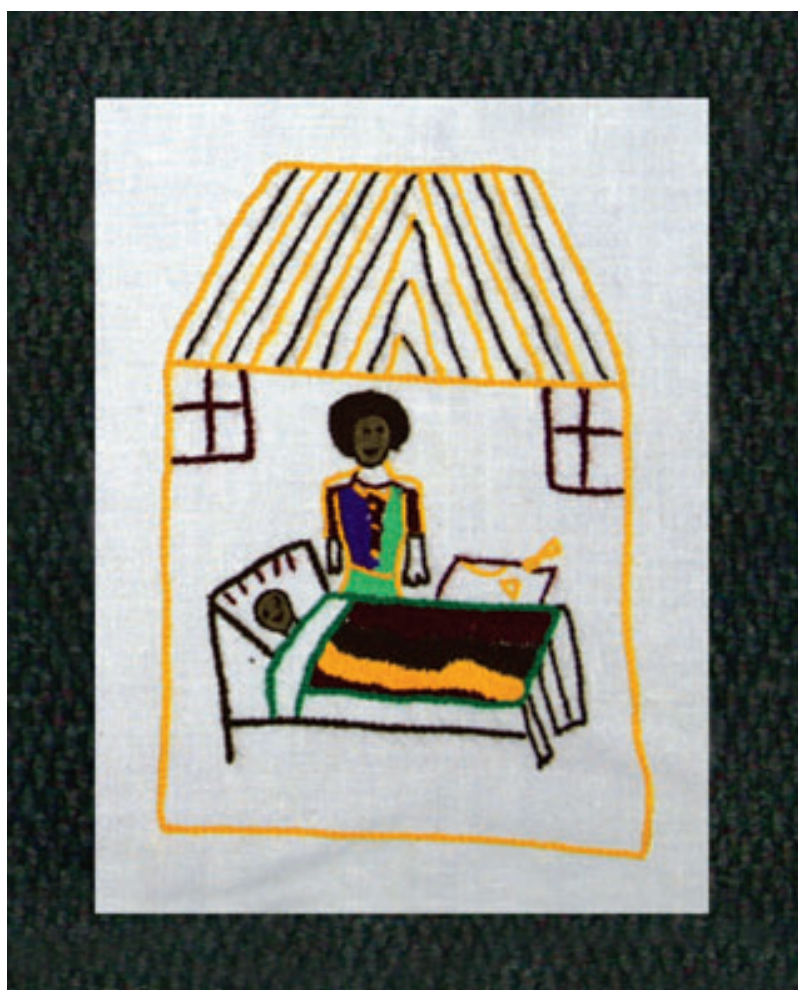

